\title{
Chromomycosis in Rhinella icterica
}

\author{
L. de Brito-Gitirana ${ }^{1, *}$ and T. Silva-Soares ${ }^{2}$
}

\author{
${ }^{1}$ Laboratory of Integrative Histology, Institute of Biomedical Science, Federal University of Rio de Janeiro, Brazil \\ ${ }^{2}$ Department of Vertebrates, Nacional Museum, Federal University of Rio de Janeiro, Brazil
}

\begin{abstract}
The integuments of five toads (Rhinella icterica) were histologically analyzed and two of them exhibited brownish encapsulated subcutaneous mass of the integument. Fungal elements involved by multinucleated histiocytic giant cells were restrict to the hypodermis. This granulomatous inflammatory process showed an extracellular matrix rich in a hyaluronic acid. Moreover, these areas were surrounded by fibrous connective tissue, where collagenous fibers predominate. Since chromomycosis was previously reported in a bufonid from Amazon region and this work was first in Southeast from Brazil, it is possible that this disease may be spread to other Brazilian regions.
\end{abstract}

Keywords: Chromomycosis, histopathology, integument, bufonid, Rhinella icterica.

\section{INTRODUCTION}

Although amphibians produce a wide variety of substances produced by cutaneous glands, helping against environmental pathogens, the close relationship to the environment makes these animals susceptible to various microbes [1-3]. A diversity of diseases in amphibians caused by virus, bacteria and fungi have been reported, resulting in mortality of several amphibian populations [3]. Some of them have been related to amphibian decline, as chytridiomycosis among other fungal diseases.

In the past 25 years dramatic declines in amphibian populations have been reported all over the world [4-6]. Although natural population fluctuations (including amphibians) are not unusual, the general decline in amphibians - even in protected areas - is persistent and represents a real threat to biodiversity [6].

Among fungal diseases, chytridiomycosis caused by Batrachochytrium dendrobatidis (Bd) has been associated with amphibian die-offs [5, 7] and characterized through cutaneous lesions. Such lesions result in hyperkeratosis which together with the fungal plaques causes death by preventing cutaneous respiration [8]. While chytridiomycosis has been reported as the main cause of amphibian mass mortality associated with population declines [5], there is little information about fungal diseases.

Mycoses are caused by several different darkly pigmented fungi, as chromomycosis, which is usually considered as opportunistic pathogens, being characterized by ulcerative or granulomatous skin lesions and/or disseminated granuloma on internal organs. In human, chromomycosis is a subcutaneous fungal infection, mainly affecting individuals in tropical and temperate regions. In addition, it affects one

*Address correspondence to this author at the Av. Carlos Chagas Filho, 373, bloco B1-019, Cidade Universitária, Rio de Janeiro, Brazil, CEP: 21941-902 Tel: 55-21-2562-6428; E-mail: lyciabg@ufrj.br leg or foot following trauma which probably occurred months before, and there is no alternative treatment for this neglected mycosis, but rather several treatment options. Most of the patients can be treated with itraconazole, terbinafine or a combination of both, but the therapy must be maintained in long-term regimens [9].

Although chromomycosis was previously reported in Rhinella marina (former Bufo marinus) [10], a terrestrial toad occurring in South American, mainly in the Amazon region [11], no report was found in other bufonids that occur in other Brazilian regions. In addition, reports on the occurrence of fungal diseases in other regions of the country can improve the knowledge about the status of this pathology.

In this work, histological description of cutaneous lesion of the integument of Rhinella icterica, a bufonid that occurs in Southwest of Brazil, was accessed in order to provide a better characterization of chromomycosis.

\section{MATERIAL AND METHODS}

Five adult males of Rhinella icterica collected according to the Brazilian laws (collecting permit no. 21319-1 IBAMA) in the district of Resende in Rio de Janeiro State were used. The animals were fixed with $10 \%$ buffered formaldehyde and maintained in glass bottle in $70 \%$ alcohol since 1996.

The integument were reexamined to histological analysis. For this, before histological analysis, post-mortem examinations were performed on all toads, and the internal side of the integument from the abdomen was macroscopically analyzed in order to find brownish areas that indicate cutaneous lesions. After that, fragments of the integuments with this macroscopic signal were removed and processed according to the standard histological technique for paraffin embedding. Five micrometer slices were then stained with hematoxilin-eosin and Gomori's trichrome staining [12]. Staining with $1 \%$ Alcian blue (AB) $8 \mathrm{GX}$ at both $\mathrm{pH} 1.0$ and $\mathrm{pH} 2.5$ 
(Kiernan, 1990) was employed for demonstration of sulfated, and sulfated and carboxylated forms of glycosaminoglycans (GAGs), respectively. The $0.05 \%$ AB 8GX at different critical electrolytic concentrations (CEC), with and without hyaluronidase (Merck) pre-treatment, was used to detect the glycosaminoglycans types [12,13]. In addition, the picrosirius red polarization method was used to visualize the arrangement of collagenous fibers [14]. After that, slices were observed under a Leica DMLS microscopy, and the images were captured using the Leica DFC 425 digital camera.

\section{RESULTS}

The integument of Rhinella icterica showed its usual histological structure, i.e., it is formed by an epidermis and a dermis, being the epidermis a keratinized squamous stratified epithelium with flask cells among the keratinocytes of the superficial layer. The dermis is subdivided into a spongious dermis and a compact dermis. Underneath the compact dermis, blood vessels and nerves occur in the loose connective tissue of the hypodermis (Fig. 1).

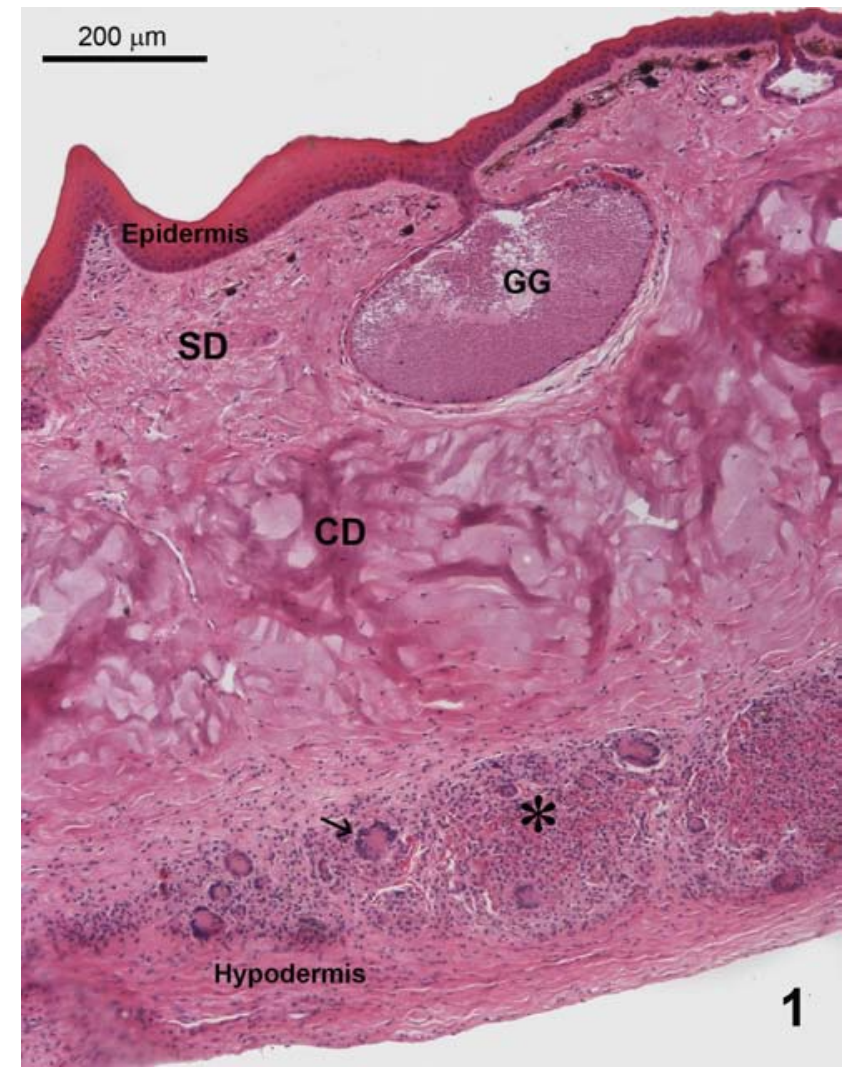

Fig. (1). Light micrograph of the integument of the dorsal region of Rhinella icterica. Note granulomatous area (*) in the hypodermis, showing multinucleated histiocytic giant cells $(\rightarrow)$. SD $=$ spongious dermis; $\mathrm{CD}$ = compact dermis; GG = granular gland. HE-staining.

After morphological examination, brownish lesion was macroscopically identified only in two toads, on the internal side of the ventral and dorsal integument. The histological analysis showed that cystic lesions are surrounded by fibrous connective tissue, being restricted to the hypodermis (Fig. 1, 2, 3 and 4). These areas exhibited a dense inflammatory infiltrate composed predominantly of mononuclear cells and some foreign body giant cells intermingled with polymorphonuclear leukocytes (Fig. 2). Outside these specific areas, the remained integument showed its usual morphology.

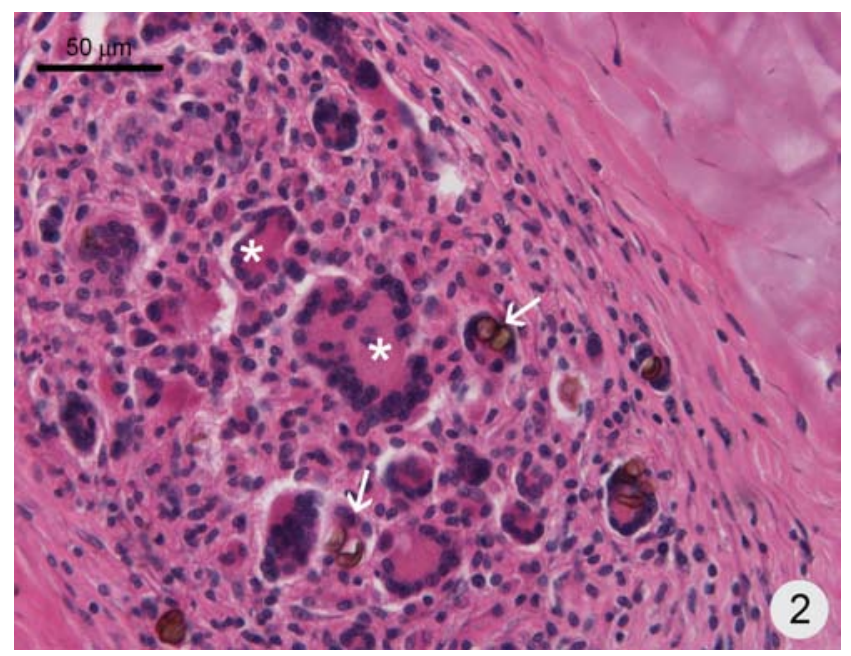

Fig. (2). Detail of the granuloma. Fungal elements $(\rightarrow)$ are visualized within multinucleated phagocytic giant cells $(*)$. HE-staining.

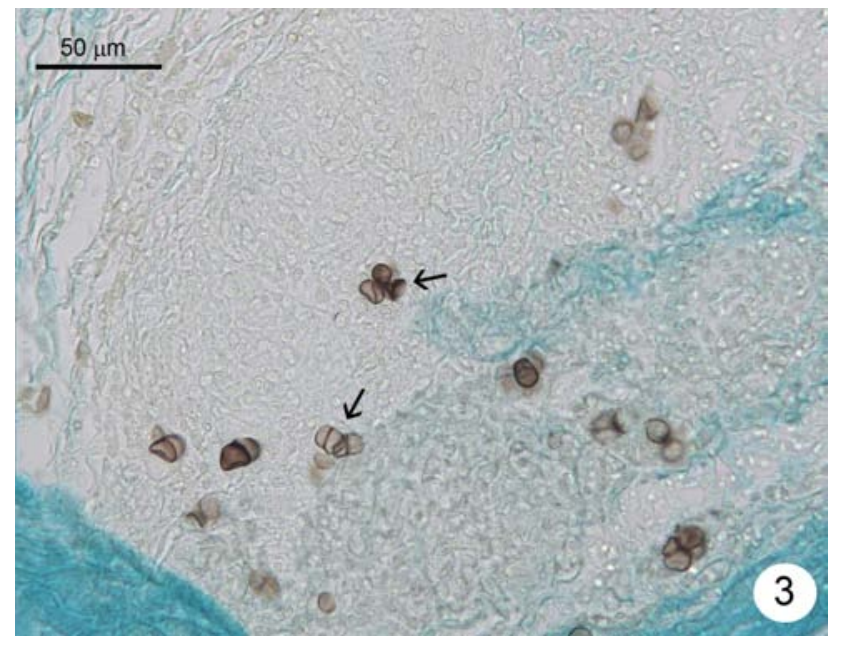

Fig. (3). Light micrograph of the integument staining with Alcian blue at $\mathrm{pH} 2.5$ with hyaluronidase pre-treatment. In the granuloma region, the alcianophilic staining disappeared when compared to the hypodermis $(*)$, indicating that the extracellular matrix of the granuloma is rich in hyaluronan.

Several fungi occur as dark-walled cells, sometimes dividing cells, named sclerotic cells. Nevertheless, the fungi were observed within multinucleated phagocytic cells (Fig. 2).

After using the $\mathrm{AB}$ staining at $\mathrm{MgCl}_{2} 0.05 \mathrm{M}$, a strong response in the infiltrated area was observed, indicating hyaluronic acid in the extracellular matrix; moreover, when the slices were pre-treated with hyaluronidase, the positive reaction disappeared (Fig. 5), demonstrating the removal of the hyaluronic acid. 


\section{DISCUSSION}

Although the integument of Rhinella icterica has been described $[15,16]$, this work is the first relate of chromomy

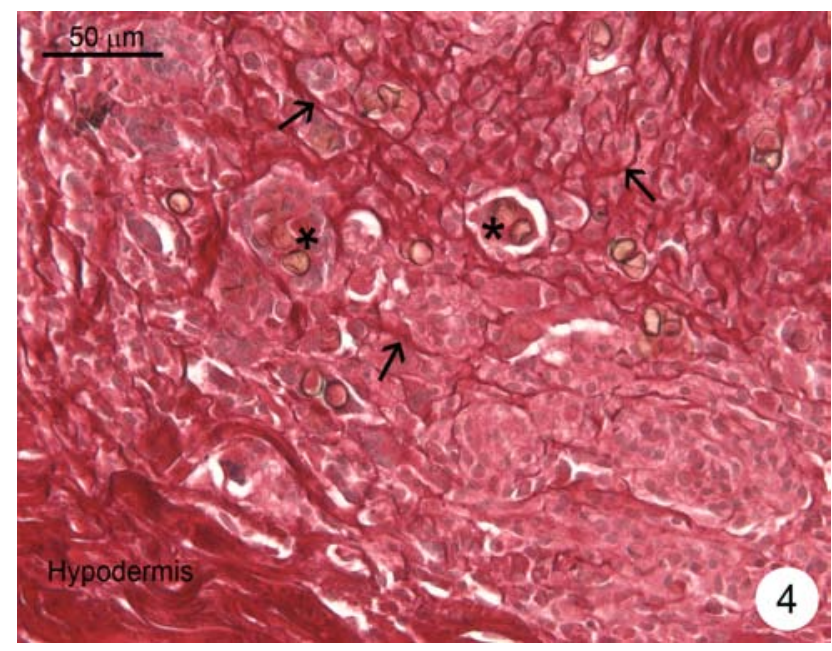

Fig. (4). In the granuloma, several collagenous fibers $(\rightarrow)$ are visualized intermingled polymorphic cells and giant cells with fungal elements $(*)$.

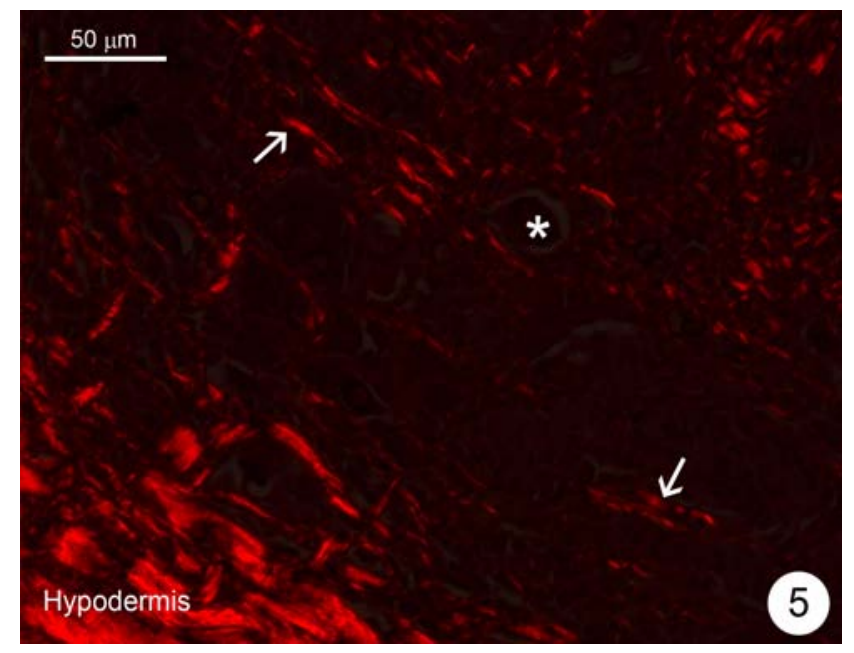

Fig. (5). Under polarized light microscope, thick collagenous fibers $(\rightarrow)$ are visualized in red intermingled polymorphic cells, but they are absent around giant cells containing fungal elements (*). Picrosirius red polarization method.

cosis in the integument of Rhinella icterica. In this bufonid, no external lesions were visualized, being restricted to the internal side of the integument, i.e., to the hypodermis. The remained integument showed its typical morphology without any histological alteration nor in the epidermis nor in the dermis. Nevertheless, rounded fungal bodies were visualized within multinucleated cells, which were immersed in a granulation extracellular matrix rich in hyaluronic acid.

Hyaluronic acid or hyaluronan (HA), an anionic nonsulfated glycosaminoglycan, is present in $R$. icterica integument [17] and widely distributed throughout connective, epithelial, and neural tissues [18]. Furthermore, HA play a role in distributing regulatory factors, regulating the movement and proliferation of cells such as inflammatory cells [19]. A variety of cell functions that are essential for tissue repair may be attributed to this HA-rich network. These functions include facilitation of cell migration into the provisional wound matrix, cell proliferation and organization of the granulation tissue matrix [19]. Thus, HA is important to macrophage migration, being significant to integument immune defense, since it plays an important modulatory role and has a protective role in the inflammatory process [20].

In amphibians, the pathogenesis of chromomycosis is not entirely elucidated. In 2003, Parré and his coworkers reported that, as an opportunist microorganism, the fungus penetrates through the integument and forms granulomatous lesions. Furthermore, chromomycosis has been related in Rhinella marina (former Bufo marinus), Rana pipiens, Pyxicephalus adspresus, and Ceratophrys ornata [10, 2124]. Although chromomycosis affects people, its transmission from amphibians to people has not been reported. According to Pessier, it occurs as ulcers, often associated with nodular lesions that can be pigmented as gray to black [3]. In humans, chromomycosis is a chronic localized invasive fungal infection of skin and subcutaneous tissues characterized by verrucous plaques on the leg or foot, caused by dematiaceous (dark-colored) fungi [24].

The immune response is a very complex process, involving several cells and substances, such as growth factors, cytokines, etc., generated in the inflammation process. In granuloma, macrophages often fuse to form multinucleated giant cells. Nevertheless, mononuclear phagocytes (monocytes, macrophages) are distributed across all the body tissues and play a central role in maintaining homeostasis, being essential for innate host defense against infection [25], involving several molecules.

Considering that chromomycosis, previously related in $R$. marina, was identified in the hypodermis of two specimens of $R$. icterica, exhibiting the rest of the integument its normal morphology, this disease probably does not cause severe cutaneous lesion. However, the occurrence of chromomycosis in bufonid of the Southeast of Brazil indicates that this disease is no longer limited in the North region, but it is not possible to clarify if the human is responsible for spreading of this disease. In addition, histological characterization of chromomycosis in amphibians is crucial to provide more knowledge about this pathology.

\section{ACKNOWLEDGEMENTS}

None declared.

\section{CONFLICT OF INTEREST}

The authors confirm that this article content has no conflicts of interest.

\section{REFERENCES}

[1] Daly JW, Myers CW, Whittaker N. Further classification of skin alkaloids from neotropical poison frogs (Dendrobatidae), with a general survey of toxic/noxious substances in the amphibian. Toxicon 1987; 25: 1023-95.

[2] Erspamer V. Bioactive secretions of the amphibian integument. In: Heatwole G, Barthalmus T, Heatwole AY. Amphibian Biology. Chipping Norton: Surrey Beatty \& Sons 1994; pp. 178-350. 
[3] Pessier AP. An overview of amphibian skin disease. Sem Avian Exotic Pet Med 2002; 11 (3): 162-74.

[4] Carey C, Cohen N, Rollins-Smith L. Amphibian declines: an immunological perspective. Dev Comp Immunol 1999; 23: 459-72.

[5] Daszak P, Berger L, Cunningham AA, Hyatt AD, Green DE, Speare R. Emerging infectious diseases and amphibian population declines. Emerg Infect Dis 1999; 5: 735-48.

[6] Houlahan JE, Findlay CS, Schmidt BR, Meyer AH, Kuzmin SL. Quantitative evidence for global amphibian population declines. Nature 2000; 404: 752-75.

[7] Berger L, Speare R, Daszak P, et al. Chytridiomycosis causes amphibian mortality associated with population declines in the rain forests of Australia and Central America. Proc Natl Acad Sci USA 1998; 95: 9031-6.

[8] Berger L, Speare R, Hyatt AD. Chytrid fungi and amphibian declines: Overview, implications and future directions. In: Campbell A, Ed. Declines and disappearances of Australian Frogs. Canberra: Environment Australia 1999a; pp. 23-33.

[9] Queiroz-Telles F, Esterre P, Perez-Blanco M, Vitale RG, Salgado CG, Bonifaz A Chromoblastomycosis: an overview of clinical manifestations, diagnosis and treatment. Med. Mycol 2009; 47(1): 3-15.

[10] Bube A, Burkhardt E, Weiss R. Spontaneous chromomycosis in the marine toad (Bufo marinus). J Comp Pathol 1992; 106:73-7.

[11] Cei JM. Bufo of South America. In: Blair F, Ed. Evolution in the genus Bufo. Austin/London: Univ. Texas 1972; pp. 82-92.

[12] Lillie RD, Fullmer HM. Histopathologic technique and practical histochemistry. New York: MacGraw-Hill Book Co. 1976; pp. 208-210; 639-64.

[13] Prophet EB, Mills B, Arrington JB, Sobin LH. Laboratory Methods in Histotechnology. Armed Forces Institute of Pathology. Washingto DC: American Registry of Pathology 1994; 274 p.
[14] Dolber PC, Spach MS. Picrosirius Red Staining of cardiac muscle following Phosphomolybdic Acid Treatment. Stain Technol 1987; 62: 23-6.

[15] de Brito-Gitirana, Azevedo RA. Morphology of Bufo ictericus integument (Amphibia, Bufonidae). Micron 2005; 36: 532-8.

[16] Azevedo RA, Santana ASJ, de Brito-Gitirana L. Dermal collagen organization in Bufo ictericus and Rana catesbeiana integument (Anura, Amphibia) under the evaluation of laser confocal microscopy. Micron 2006; 37: 223-8.

[17] Azevedo RA, Carvalho HF, de Brito-Gitirana L. Hyaluronan in the epidermal and dermal extracelular matriz: its role in cutaneous hydric balance and integrity of anuran integument. Micron 2007; 38: 607-10.

[18] Raija HT, Markku IT. Hyaluronan in the epidermis and other epithelial tissues. Chemistry and Biology of Hyaluronan. Elsevier, Chapter 19, 2004; pp. 395-413.

[19] John Chen WY, Abatangelo G. Wound Rep Reg 1999; 7: 79-89.

[20] Lelenti A, di Rosa M. Hyaluronic acid modulate acute and chronic inflammation. Inflamm Res 1994; 43: 44-7.

[21] Suedmeyer WK, Gillespie DS, Pace L. Chromomycosis in a marine toad, Bufo marinus. Bull Assoc Reptil Amph Vet 1997; 7: 13-5.

[22] Ackermann J, Milker E. Chromomycosis in an African bullfrog Pyxicephalus adspersus. Bull Assoc Reptil Amph Vet 1992; 2: 8-9.

[23] Miller EA, Montali RJ, Ramsay EC, Rideout BA. Disseminated chromoblastomycosis in a colony of ornate-horned frogs (Ceratophrys ornata). J Zoo Wildlife Med 1992; 23(4): 433-8.

[24] Son YM, Kang HK, Na SY, Lee HY, Baek JO, Lee JR, Roh JY, Seo YH. Chromoblastomycosis caused by Phialophora richardsiae. Ann Dermatol 2010; 22(3): 362-6.

[25] Johnston Jr RB. Kliegman Nelson Textbook of Pediatrics $19^{\text {th }}$ ed. chapter 122. USA: Saunders 2011 pp. 873-9

(c) Brito-Gitirana and Silva-Soares; Licensee Bentham Open.

This is an open access article licensed under the terms of the Creative Commons Attribution Non-Commercial License (http://creativecommons.org/licenses/by-nc/3.0/) which permits unrestricted, non-commercial use, distribution and reproduction in any medium, provided the work is properly cited. 